\title{
Productivity Enhancement of Soybean through Improved Production Technologies in North- Eastern Transitional Zone of Karnataka
}

\author{
S. Ravi ${ }^{1 *}$, R. L. Jadhav ${ }^{1}$, N. M. Sunil Kumar ${ }^{2}$, \\ Ningdalli Mallikarjun ${ }^{1}$ and Akshaykumar ${ }^{1}$ \\ ${ }^{1}$ (Soil science, Agronomy, Horticulture and Animal science), \\ ICAR- Krishi Vigyan Kendra, Bidar -585402 Karnataka, India \\ ${ }^{2}$ Krishi Vigyan Kendra, Bidar-585402, Karnataka, India \\ *Corresponding author
}

\section{Ke y w o r d s \\ Front line demonstrations, Soybean, Extension gap, Yield and B: C \\ Article Info \\ Accepted: \\ 23 April 2020 \\ Available Online: \\ 10 May 2020}

\begin{abstract}
A B S T R A C T
Soybean is one of the important oilseed crop in India, which plays a major role in supplementing the income of small and marginal farmers. One of the major constraints of traditional soybean farming is low productivity of local varieties and nutrient deficiency in soil. In this point of view Krishi Vigyan Kendra, Bidar conducted Front line demonstration at 145 farmer's field to demonstrate production potential and economic benefit of improved technologies at adopted farmer's field during 2012-13 to 2019-20 of seven years study in rainfed condition. The results shows improved production technologies of soybean (Dsb-21) recorded increased mean (average) yield of seven years 12.38 and 18.20 $\%$ during study period over local check. The technology gap which shows the gap in the demonstration yield over potential yield were $6.80 \mathrm{q} \mathrm{ha}^{-1}$ over a seven years, The highest extension gap of 7.60 was recorded in during 2017-18 this high extension gap requires urgent attention by the extension and development agencies. The technology index is 40.0 percent during 2014-15 which shows the good performance. There is a need to adopt multipronged strategy that involves enhancing soybean production through area expansion and productivity improvements through better adoption of improved technology. The improved technologies resulted higher mean net income of Rs.59, $500 \mathrm{ha}^{-1}$ with a benefit cost ratio of 3.64 as compared to local check.
\end{abstract}

\section{Introduction}

Soybean (Glycine max L.) is considered as a natural fertilizer factory because of its high nitrogen fixing property with rhizobium. Being a leguminous crop, it is expected to improve soil fertility and productivity of succeeding crop. The crop in fact has revolutionized the agricultural economy with its immense potential for food, seed and industrial products. Soybean like most legumes performs nitrogen fixation by establishing symbiotic relationship with bacteria, Rhizobium japonicum. In India, the annual soybean production was 10.98 million tonnes with its area under cultivation was 10.47 million hectares and average productivity is $1049 \mathrm{~kg} \mathrm{ha}^{-1}$ (2017-18) Fourth advance estimates, Directorate of Economics and Statistics (New Delhi). Madhya Pradesh 
is known as the soybean bowl of India, contributing 59 per cent of the national soybean production, followed by Maharashtra (29 per cent) and Rajasthan (6 per cent) contribution. Andhra Pradesh, Karnataka, Chhattisgarh and other parts of India also produce the soybean in small quantities (Anon, 2013). In Karnataka, soybean is grown over an area of 0.32 million hectares with production of 2.91 million tonnes and productivity of $991 \mathrm{~kg} \mathrm{ha}^{-1}$ in 2018-19 according to Soybean Processors Associations of India. The actual yield potentiality of soybean had not been achieved because of existing fertilizer recommendation, as it consist of fixed rates and timing of $\mathrm{N}, \mathrm{P}$ and $\mathrm{K}$ for vast areas of production in soybean growing areas including Bidar. Such recommendations are in practice over the years in large areas. But crop growth and crop need for supplemental nutrients are strongly influenced by genotype, soil type and climate which can vary greatly among fields, seasons and years.

The soybean crop is mainly cultivated in Kharif season. Frontline demonstration on soybean using new crop production technology was initiated with the objectives of showing the productive potentials of the new production technologies under real farm situation over the locally adopted production technologies.

\section{Materials and Methods}

Frontline Demonstration is the new concept of field demonstration evolved by ICAR with the inception of technology mission on oilseeds and pulses. The main objective of frontline demonstrations is to demonstrate newly released crop production technologies and its management practices in the farmer's field. The present investigation was carried out at-adopted villages of KVK, Bidar (Karnataka state). The Frontline demonstrations 145 were organized on farmer's field to demonstrate the impact of integrated crop management technology on soybean productivity over seven years during Kharif season 2012-13 to 2019-20 (except 2016-17). Each frontline demonstration was laid out on 0.4 ha area, adjacent 0.4 ha was considered as control (farmer's practice). The integrated crop management technology fallowed (Table 1). The yield data were collected from both the demonstration and farmers practices by random crop cutting method. Qualitative data were converted into quantitative form and expressed in terms of per cent increase in yield calculated using following formula (Samui et al., 2000).

Technology gap $=$ Potential yield Demonstration

Yield Extension gap $=$ Demonstration yield Farmers yield

Technology index $=(($ Potential yield Demonstration yield) / Potential yield) x 100

\section{Results and Discussion}

During the 2012-13 to 2019-20 (except 201617) of seven years study period it was observed that the adoption of improved production technologies in demonstration trials has increased the yield over the farmers' practices. Full gap was observed in most of production technology was the reason of not achieving potential yield. Farmers were not aware about recommended technologies.

Frontline demonstration was conducted on 58 hectares of land on 145 demonstration plots. The growth and yield attributing parameters are increased with improved production technology. On an average the plant height, number of branches per plant, number of pods per plant and hundred seed weight $(\mathrm{g})$ increase were observed $68.43 \mathrm{~cm}, 6.19,84.00$ and 13.38, respectively compare to farmers practice $(45.57 \mathrm{~cm}, 3.63,55.00$ and 10.74 , 
respectively) during seven subsequent years (2012-13 to 2019-20). The result indicates that the growth and yield parameters are increased in demo plots compare to farmers practice due to improved production technology such as improved variety, seed treatment with biofertlizers and early weed control, high seed rate will help for the plants to grow properly. The result indicates that the frontline demonstration has given a good impact over the farming community of Bidar (North-Eastern transitional zone of Karnataka) as they were motivated by the new agricultural technologies applied in the FLD plots.

The data in table 3 revealed that, the soybean variety Dsb-21 yielded $18.20 \mathrm{q} \mathrm{ha}^{-1}$ which was $31.92 \%$ higher yield over farmers practice $\left(12.38 \mathrm{q} \mathrm{ha}^{-1}\right.$ ) during the $2012-13$ to 2019-20 of seven years study. The highest yield of $20.50 \mathrm{q} \mathrm{ha}^{-1}$ was observed in 2015-16 and lowest yield $15.00 \mathrm{q} \mathrm{ha}^{-1}$ in 2014-15 due to moisture availability and deficiency of rainfall (Poonia and Pithia, 2011). The result indicates that the frontline demonstration has given a good impact over the farming community of Bidar (North-Eastern transitional zone of Karnataka) as they were motivated by the new agricultural technologies applied in the FLD plots. Yield of soybean was varied in different years, which might be due to the soil moisture availability \& rainfall condition, climatic aberrations, disease and pest attacks as well as the change in the location of trials every year. The percentage increase in the yield over local check was 25.0, 36.22, 34.33, 36.58, $39.27,26.30$ and 25.71 during seven subsequent years (2012-13 to 2019-20) over a farmer check. The increased seed yield with improved technologies was mainly because of line sowing with wider spacing, use of nutrient management and timely weed management. The reason for this could be the inter plant competition for the moisture and nutrients which could be more severe under local check demonstration (Farmers practice). Also, the higher weed infestation under the local check as evident from the higher weed cover and reduced the amount of nutrients and water available to the local check. This may be attributed to sufficient and more than average rainfall distributed fairly during the pod setting to physiological maturity stage, better utilization of applied nutrients (Poonia and Pithia, 2011). This increase in number of branches per plant and seed yield may be due to higher physiological efficiency and photosynthetic rates the findings are in line with Anand et al., (2017) in soybean.

The economic viability of improved technologies over traditional farmer's practices was calculated depending on prevailing prices of inputs and output costs (Table 3). The results revealed that the FLD plots increased higher gross return, net return and B: C ratio of Rs. $66,475 \mathrm{ha}^{-1}$, Rs. $45,615.7$ $\mathrm{ha}^{-1}$, 3.16, respectively as against farmers practice (local check) Rs. 45,323.6 ha ${ }^{-1}$, Rs. 28,592.1 ha $^{-1}, 2.72$, respectively. The highest net return observed in Rs 59,500 ha ${ }^{-1}$ in the 2015-16. The additional cost increased in the improved technologies was mainly due to more cost involved in balanced fertilizer, improved seed and weed management practices. Similar results also have been reported by Khan et al., (2009). To get maximum yield of soybean recommended package of practices should be followed. By not following any one management practice yield may be reduced severely and it was also observed that delay in sowing, unbalanced does of fertilizer, untimely weed management and plant protection drastically reduced the seed yield of soybean.

The technology gap in the demonstration yield for soybean ranges from 4.50 to 10.0. The technological gap may be attributed to the dissimilarity in the soil fertility status and 
weather conditions (Mukharjee, 2003). The extension gap ranges from 4.50 to 7.60 during seven years of FLDs for soybean. The technology index of soybean was ranges from 18.0 to 40.0 . This emphasized the need to educate the farmers through various means for the adoption of improved agricultural production technologies to reverse this trend of wide extension gap.

On the basis of the result obtained in present study it can be concluded that use of improved method of soybean cultivation can reduced the technology gap to a considerable extent thus leading to increase productivity of soybean in the district. Extension gap emphasis the need to educate the farmers through various means like village level training, on campus training, method demonstration, front line demonstration, etc. Technology index which shows the feasibility of the technology demonstrated has depicted good performance of the intervention.

Table.1 Improved production technology and Farmers practices of soybean under FLD

\begin{tabular}{|c|c|c|c|c|}
\hline SI No. & Technology & Improved practices & Farmers practice & GAP $(\%)$ \\
\hline 1 & Variety & Dsb-21 & Local & 100 \\
\hline 2 & Land preparation & Ploughing and harrowing & $\begin{array}{l}\text { Ploughing and } \\
\text { harrowing }\end{array}$ & Nill \\
\hline 3 & Pre emergent herbicide & Pendimethalin (@3.3 lit ha ${ }^{-1}$ ) & No herbicide & Full gap \\
\hline 4 & Seed rate & $62.5 \mathrm{~kg} \mathrm{ha}^{-1}$ & $50 \mathrm{~kg} \mathrm{ha}^{-1}$ & Partial gap \\
\hline 5 & Sowing method & $\begin{array}{l}\text { Line sowing with wider space } \\
\qquad 45 \times 10 \mathrm{~cm}\end{array}$ & $\begin{array}{l}\text { Line sowing with } \\
\text { close spacing } \\
30 \times 10 \mathrm{~cm}\end{array}$ & No gap \\
\hline 6 & Seed treatment & $\begin{array}{c}\text { Rhizobium(strain-1), PSB and } \\
\text { Biojaim }\end{array}$ & No seed treatment & Full gap \\
\hline 7 & Fertilizer dose $\left(\mathrm{kg} \mathrm{ha}^{-1}\right)$ & $\begin{array}{c}40: 80: 25 \mathrm{~kg} \mathrm{ha}^{-1} . \mathrm{NPK}+30 \\
\mathrm{~kg} \mathrm{ha}^{-1} \mathrm{~S}+12.5 \mathrm{~kg} \mathrm{ha}^{-1} \\
\mathrm{ZnSO}_{4} 7 \mathrm{H}_{2} \mathrm{O}+1.0 \mathrm{~kg} \mathrm{ha}^{-1} \\
\text { boron }\end{array}$ & $\begin{array}{c}\text { 20:40:10 NPK kg } \\
\text { ha }^{-1}\end{array}$ & Partial gap \\
\hline 8 & Plant protection & IPM & $\begin{array}{l}\text { Indiscriminate } \\
\text { application }\end{array}$ & Full gap \\
\hline 9 & Grading the produce & Grading the produce & Not followed & Full gap \\
\hline
\end{tabular}


Table.2 Details of soybean growing under existing farmer's practices and improved practices adopted in frontline demonstrations at farmer's field in north eastern transitional zone of Karnataka

\begin{tabular}{|c|c|c|c|c|c|c|c|c|c|c|c|}
\hline \multirow[t]{2}{*}{ Year } & \multicolumn{2}{|c|}{$\begin{array}{l}\text { Plant height } \\
\text { (cm) }\end{array}$} & \multicolumn{2}{|c|}{$\begin{array}{l}\text { No. Branches } \\
\text { plant }^{-1}\end{array}$} & \multicolumn{2}{|c|}{$\begin{array}{l}\text { No. of pods } \\
\text { plant }^{-1}\end{array}$} & \multicolumn{2}{|c|}{$\begin{array}{l}100 \text { Seed } \\
\text { weight }(g)\end{array}$} & \multicolumn{2}{|c|}{$\begin{array}{l}\text { Seed Yield } \\
\quad\left(\mathbf{q} \mathbf{h a}^{-1}\right)\end{array}$} & \multirow{2}{*}{$\begin{array}{c}\% \\
\text { Increase } \\
\text { yield }\end{array}$} \\
\hline & Demo & Check & Demo & Check & Demo & Check & Demo & Check & Demo & $\begin{array}{c}\text { Chec } \\
\mathbf{k}\end{array}$ & \\
\hline 2012-13 & 54 & 45 & 4.9 & 3.5 & 74 & 58 & 13.15 & 11.60 & 20.00 & 15.00 & 25.00 \\
\hline 2013-14 & 63 & 49 & 5.8 & 3.9 & 70 & 61 & 12.60 & 11.80 & 17.79 & 11.32 & 36.36 \\
\hline 2014-15 & 56 & 42 & 5.6 & 3.0 & 77 & 59 & 11.69 & 10.75 & 15.00 & 9.85 & 34.33 \\
\hline 2015-16 & 74 & 46 & 6.9 & 3.5 & 90 & 55 & 14.00 & 10.50 & 20.50 & 13.00 & 36.58 \\
\hline 2017-18 & 76 & 48 & 6.8 & 3.7 & 95 & 52 & 14.30 & 10.25 & 19.35 & 11.75 & 39.27 \\
\hline 2018-19 & 73 & 43 & 6.6 & 4.3 & 89 & 48 & 13.80 & 10.10 & 17.30 & 12.75 & 26.30 \\
\hline 2019-20 & 83 & 46 & 6.7 & 3.5 & 93 & 52 & 14.10 & 10.21 & 17.50 & 13.00 & 25.71 \\
\hline Average & 68.43 & 45.57 & 6.19 & 3.63 & 84.00 & 55.00 & 13.38 & 10.74 & 18.21 & 12.38 & 31.94 \\
\hline
\end{tabular}


Table.3 Seed yield and economics of soybean as affected by improved and local practices in farmers fields

\begin{tabular}{|c|c|c|c|c|c|c|c|c|c|c|c|c|c|c|}
\hline \multirow[t]{2}{*}{ Year } & \multirow[t]{2}{*}{$\begin{array}{l}\text { No of } \\
\text { Demo. }\end{array}$} & \multirow[t]{2}{*}{$\begin{array}{c}\text { Area } \\
\text { (ha) }\end{array}$} & \multicolumn{3}{|c|}{ Yield $\left(q\right.$ ha $\left.^{-1}\right)$} & \multirow{2}{*}{$\begin{array}{c}\% \\
\text { increase } \\
\text { in yield } \\
\text { over } \\
\text { farmers } \\
\text { practice }\end{array}$} & \multicolumn{2}{|c|}{$\begin{array}{l}\text { Cost of cultivation } \\
\left(\text { Rs. } \text { ha }^{-1}\right)\end{array}$} & \multicolumn{2}{|c|}{$\begin{array}{l}\text { Gross return } \\
\quad\left(\text { Rs. ha }{ }^{-1}\right)\end{array}$} & \multicolumn{2}{|c|}{$\begin{array}{l}\text { Net return } \\
\left(\text { Rs. ha }{ }^{-1}\right)\end{array}$} & \multicolumn{2}{|c|}{ B:C } \\
\hline & & & $\begin{array}{l}\text { Potential } \\
\text { yield }\end{array}$ & $\begin{array}{c}\text { Demo } \\
\text { yield }\end{array}$ & $\begin{array}{c}\text { Farmers } \\
\text { practice }\end{array}$ & & Demo & Check & Demo & Check & Demo & Check & Demo & Check \\
\hline 2012-13 & 5 & 2 & 25 & 20.0 & 15.00 & 25.00 & 21475 & 17850 & 74000 & 55500 & 52525 & 37650 & 3.44 & 3.10 \\
\hline 2013-14 & 5 & 2 & 25 & 17.75 & 11.32 & 36.22 & 16720 & 11310 & 56800 & 36240 & 40080 & 24930 & 3.30 & 3.20 \\
\hline 2014-15 & 25 & 10 & 25 & 15.00 & 9.85 & 34.33 & 18220 & 12810 & 52500 & 34475 & 34280 & 21665 & 2.80 & 2.60 \\
\hline 2015-16 & 25 & 10 & 25 & 20.50 & 13.00 & 36.58 & 22500 & 18900 & 82000 & 52000 & 59500 & 33100 & 3.64 & 2.75 \\
\hline 2017-18 & 25 & 10 & 25 & 19.35 & 11.75 & 39.27 & 21500 & 18250 & 67725 & 41125 & 46225 & 22875 & 3.15 & 2.25 \\
\hline 2018-19 & 30 & 12 & 25 & 17.30 & 12.75 & 26.30 & 22500 & 18500 & 60550 & 44625 & 38050 & 26125 & 2.69 & 2.41 \\
\hline 2019-20 & 30 & 12 & 25 & 17.50 & 13.00 & 25.71 & 23100 & 19500 & 71750 & 53300 & 48650 & 33800 & 3.11 & 2.73 \\
\hline Average & 20.71 & 8.29 & 25.0 & 18.20 & 12.38 & 31.92 & 20859.3 & $\begin{array}{c}16731 \\
4\end{array}$ & $\begin{array}{c}66475 . \\
0\end{array}$ & $\begin{array}{c}45323 . \\
6\end{array}$ & $\begin{array}{c}45615 . \\
7\end{array}$ & $\begin{array}{c}28592 . \\
1\end{array}$ & 3.16 & 2.72 \\
\hline Total & 145 & 58 & - & - & - & - & - & - & - & - & - & - & - & - \\
\hline
\end{tabular}


Table.4 Performance of Front Line Demonstrations (FLD) of soybean in north - eastern transitional zone of Karnataka

\begin{tabular}{|c|c|c|c|c|c|c|c|c|c|}
\hline \multirow[t]{2}{*}{ Year } & \multirow{2}{*}{$\begin{array}{l}\text { No of } \\
\text { Demo. }\end{array}$} & \multirow{2}{*}{$\begin{array}{c}\text { Area } \\
\text { (ha) }\end{array}$} & \multicolumn{3}{|c|}{ Yield $\left(q\right.$ ha $\left.^{-1}\right)$} & \multirow{2}{*}{$\begin{array}{c}\text { \% increase } \\
\text { in yield over } \\
\text { farmers } \\
\text { practice }\end{array}$} & \multirow{2}{*}{$\begin{array}{c}\text { Technological } \\
\underset{\left(\mathbf{q ~ h a p}^{-1}\right)}{ }\end{array}$} & \multirow{2}{*}{$\begin{array}{l}\text { Extension } \\
\underset{\text { gap }}{\left(\mathbf{q ~ h a}^{-1}\right)}\end{array}$} & \multirow{2}{*}{$\begin{array}{l}\text { Technological } \\
\text { index } \\
(\%)\end{array}$} \\
\hline & & & $\begin{array}{l}\text { Potential } \\
\text { yield }\end{array}$ & Demo & $\begin{array}{l}\text { Farmers } \\
\text { practice }\end{array}$ & & & & \\
\hline 2012-13 & 5 & 2 & 25 & 20.0 & 15.00 & 25.00 & 5.00 & 5.00 & 20.0 \\
\hline 2013-14 & 5 & 2 & 25 & 17.75 & 11.32 & 36.22 & 7.25 & 6.43 & 29.0 \\
\hline 2014-15 & 25 & 10 & 25 & 15.00 & 9.85 & 34.33 & 10.00 & 5.15 & 40.0 \\
\hline $2015-16$ & 25 & 10 & 25 & 20.50 & 13.00 & 36.58 & 4.50 & 7.50 & 18.0 \\
\hline 2017-18 & 25 & 10 & 25 & 19.35 & 11.75 & 39.27 & 5.65 & 7.60 & 22.6 \\
\hline 2018-19 & 30 & 12 & 25 & 17.30 & 12.75 & 26.30 & 7.70 & 4.55 & 30.8 \\
\hline 2019-20 & 30 & 12 & 25 & 17.50 & 13.00 & 25.71 & 7.50 & 4.50 & 30.0 \\
\hline Average & 20.71 & 8.29 & 25.0 & 18.20 & 12.38 & 31.92 & 6.80 & 5.82 & 27.2 \\
\hline Total & 145 & 58 & - & - & - & - & - & - & - \\
\hline
\end{tabular}




\section{References}

Anand, G. P., Halepyati, A. S and Chittapur, B. M., 2017, Influence of site specific nutrient management on growth and yield of soybean in north eastern transitional zone of Karnataka. Bio. Scan, 12(1): 287-290.

Anonymous, 2013, http://www.icexindia. com/profiles_html/soybean.html.

Khan, M.A.H, Sultana, N.A., Islam, M.N., Hasanuzzaman, M., (2009) Yield and yield contributing of Sesame as affected by different management practices.
Am.-Eur. J. Sci. Res. 4(3):195-197.

Mukherjee, N., (2003) Participatory, learning and action. Concept Publishing Company, New Delhi, pp.63-65.

Poonia, T.C and Pithia, M.S., (2011) Impact of front line demonstrations of chickpea in Gujarat. Legume Research. 34(4): 304-307

Samui S. K., Maitra S., Roy, D.K., Mondal, A. K and Saha D., (2000) Evaluation on Frontline Demonstration on Groundnut (Arachis hypogeal L.). Journal of the Indian Society of Coastal Agriculture Research.18 (2):180-183.

\section{How to cite this article:}

Ravi, S., R. L. Jadhav, N. M. Sunil Kumar, Ningdalli Mallikarjun and Akshaykumar. 2020. Productivity Enhancement of Soybean through Improved Production Technologies in NorthEastern Transitional Zone of Karnataka. Int.J.Curr.Microbiol.App.Sci. 9(05): 2885-2892. doi: https://doi.org/10.20546/ijcmas.2020.905.331 